\title{
A REVIEW OF PUBLISHED DATA ON ACRIDINE DERIVATIVES WITH DIFFERENT BIOLOGICAL ACTIVITIES
}

\author{
Jelena S. Rupar'1, Vladimir D. Dobričić ${ }^{2 *}$, Mara M. Aleksić1, \\ Jasmina S. Brborić ${ }^{2}$, Olivera A. Čudina ${ }^{2}$ \\ ${ }^{1}$ University of Belgrade, Faculty of Pharmacy, Department of Physical Chemistry \\ Vojvode Stepe 450, 11000 Belgrade, Serbia \\ ${ }^{2}$ University of Belgrade, Faculty of Pharmacy, Department of Pharmaceutical Chemistry \\ Vojvode Stepe 450, 11000 Belgrade, Serbia \\ *Corresponding author; E-mail: vladimir@ pharmacy.bg.ac.rs
}

(Received January 24, 2018; Accepted March 27, 2018)

\begin{abstract}
Acridine ring can be found in molecules used in many different spheres, including industry and medicine. Nowadays, even acridines with antibacterial activity are of research interest due to increasing bacterial resistance. Some acridine derivatives showed antimalarial or antiviral activity. Acridine derivatives were also investigated for antitumor activity due to the interaction with topoisomerase II and DNA base pairs. Considering these possible uses of acridine derivatives, this work was made as overview of all significant structure characteristics for specific action of these compounds.
\end{abstract}

Keywords: acridine, antiparasitic, antibacterial, antiviral, antitumor activity, DNA.

\section{INTRODUCTION}

Acridines are compounds known ever since 19th century. When these substances were isolated from crude anthracene, one of them was named acridine (acridine means sharp, painful) since it had itching and inflammatory properties (REINHARDT and TRAVIS, 2000). Correct structure of acridine was established by Carl Riedel, who also established acridine, quinoline and pyridine structure relationships. Almost at the same time, acridine was successfully synthesized (REINHARDT and TRAVIS, 2000). Structure of acridine and its numeration are shown in Fig. 1 (GRAEBE and LAGODZINSKI, 1893). Acridine can also be named as 10-azaanthracene and dibenzo[b,e]pyridine.<smiles>c1ccc2nc3ccccc3cc2c1</smiles>

Figure 1. Acridine structure and numeration. 
Acridine ring can be found in molecules used in many different spheres, including industry and medicine (ALBERT, 1966; BROWNING, 1937; BROWNING, 1964).

Acridine derivatives, such as acriflavine and proflavine, were used during the World War I as topical antibacterial agents. Later, quinacrine was discovered and used during World War II as antimalarial agent (NASIM and BRYCHCY, 1979). Chemical structures of these acridine derivatives are presented in Fig. 2.
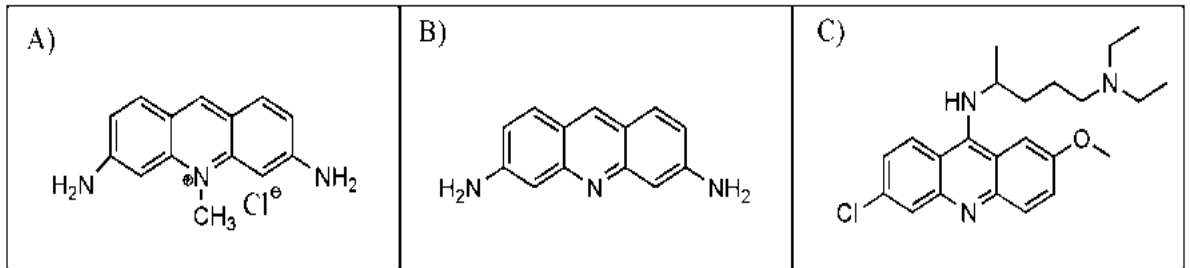

Figure 2. Chemical structure of several acridine derivatives:

A) acriflavine; B) proflavin; C) quinacrine.

Soon after World War II, penicillines and other antibiotics replaced acridine based drugs with antibacterial properties. However, other acridine derivatives which had different targets were still in use. Nowadays, even acridines with antibacterial activity are of research interest due to increasing bacterial resistance (KUMAR et al., 2012).

During 1980s, many antitumor drugs which were in clinical trials or in clinical use actually interacted with DNA. One of those derivatives was 4'-(9acridinylamino)methanesulphon-m-anisidide (m-AMSA) (Fig. 3). m-AMSA was developed as a result of SAR study conducted on sulfonanilide ring substituted compounds (CAIN et al., 1975). These authors used murine L1210 leukemia cells as a test system, while BAGULEY and NASH (1981) showed later good correlation between in vitro and in vivo antitumor activity using the same cells.<smiles>COc1cc(N(C)C(C)=O)ccc1Nc1c2ccccc2nc2ccccc12</smiles>

Figure 3. Chemical structure of $m$-AMSA.

Rowe et al. (1986) proved theory that activity of DNA topoisomerase II may be affected by antitumor acridines, including m-AMSA. Several other groups of acridine derivatives also have antibacterial (BROWNING et al., 1922; ALBERT et al., 1949) and antitumor activity (JIANG et al., 2016; CUI et al., 2016).

Some acridine derivatives showed antimalarial activity (CHAVALITSHEWINKOON et al., 1993; Coggeshall, 1952). According to Chavalitshewinkoon et al. (1993), 9anilinoacridines with specific substituents inhibited the decatenation activity of Plasmodium falciparum DNA topoisomerase II. 
SUVEYZDIS et al. (2000) published a research which confirmed that some aminoacridine derivatives possess antiviral activity.

\section{ACRIDINE-DNA INTERACTIONS}

Acridine derivatives can interact with DNA by intercalating between DNA base pairs (PEACOCKE and SKERRETT, 1956; RAMSTEIN et al., 1972; GEORGHIOU, 1975). The interaction of acridine with DNA was also evaluated by CHOUDHURY and BASU (1995), using absorption and fluorescence spectroscopy. DNA based electrochemical biosensors were successfully used for investigation of interactions between DNA and other molecules (DICULESCU et al., 2016; AlEKSIĆ and KAPETANOVIĆ, 2013; AlEKSIĆ and KAPETANOVIĆ, 2014), such as proteins (ŽIVANOVIĆ et al., 2010) and different drugs (RADULOVIĆ et al., 2012a; RADULOVIĆ et al., 2012b; PANTIĆ et al., 2016; LIJESKIĆ et al., 2014).

Different electrodes may be used in voltammetric methods with aim to prove electroactivity of compounds containing acridine ring (GIROUSI et al., 2008; PONTINHA et al., 2013). PANTIĆ et al. (2016) proved interaction of 9-chloroacridine with double-stranded calf thymus DNA using square wave voltammetry and DNA-modified glassy carbon electrode.

\section{ANTIPARASITIC ACTIVITY OF ACRIDINE DERIVATIVES}

Antimalarial activity of acridine derivatives is based on several mechanisms of action: hemozoin targeting (KUMAR et al., 2007), DNA topoisomerase inhibition (FERGUSON and DENNY, 2007; CHAVALITSHEWINKOON et al., 1993), folate metabolism inhibition (SANTELLIROUVIER et al., 2004) and plasmepsin II inhibition (AZIM et al., 2008).

SANTELLI-ROUVIER et al. (2004) synthesized arylacridinylsulfones which showed activity against Plasmodium falciparum. These compounds (Fig. 4) showed activity due to structural similarity with dapsone and its derivatives (POPOFF et al., 1971) or acridine derivatives (FIGGITT et al., 1992). According to SANTELLI-ROUVIER et al., activities were not dependent on the presence of para-aminobenzoic acid (PABA) and acridine ring was part of the compounds responsible for the particular antimalarial activity. The sulfone group is also important for their activity. These authors suggested that there might be relationship between the activity and the ability of cleavage of the S-9C bond in acridine compound structure.

AZIM et al. (2008) used virtual screening for identification of acridine derivatives which may have significant activity against $P$. falciparum. They showed that potency was improved, and selective aspartic protease activity was achieved with different substituents (Fig. 5).

YU et al. (2012) synthesized new $N$-alkylaminoacridine derivatives (Fig. 6) with heterocyclic ring in the position $\mathrm{C} 9$ which significantly increased the activity against $P$. falciparum. Compounds with chloro and methoxy substituents in the acridine structure had higher inhibitory activity on the $\beta$-hematin formation, but inhibition was not in correlation with antimalarial activity. Morpholinyl compounds showed modest activity and also were highlighted for antimalarial activity by other authors (OPSENICA et al., 2011). 


\begin{tabular}{|c|c|c|c|}
\hline Compound & $\mathrm{R}_{\mathrm{i}}$ & $\mathrm{R}_{2}$ & $\mathrm{R}_{3}$ \\
\hline 1 & & ${ } \mathrm{OCH}_{3}$ & $-\mathrm{H}$ \\
\hline 2 & & $-\mathrm{H}$ & $-\mathrm{Cl}$ \\
\hline 3 & & $-\mathrm{OCH}_{3}$ & $-\mathrm{Cl}$ \\
\hline 4 & & $-\mathrm{OCH}_{3}$ & $-\mathrm{Cl}$ \\
\hline 5 & & $-\mathrm{OCH}_{3}$ & $-\mathrm{Cl}$ \\
\hline 6 & & $-\mathrm{OCH}_{3}$ & $-\mathrm{Cl}$ \\
\hline 7 & & $-\mathrm{OCH}_{3}$ & $-\mathrm{Cl}$ \\
\hline
\end{tabular}

Figure 4. Arylacridinyl sulfones. 


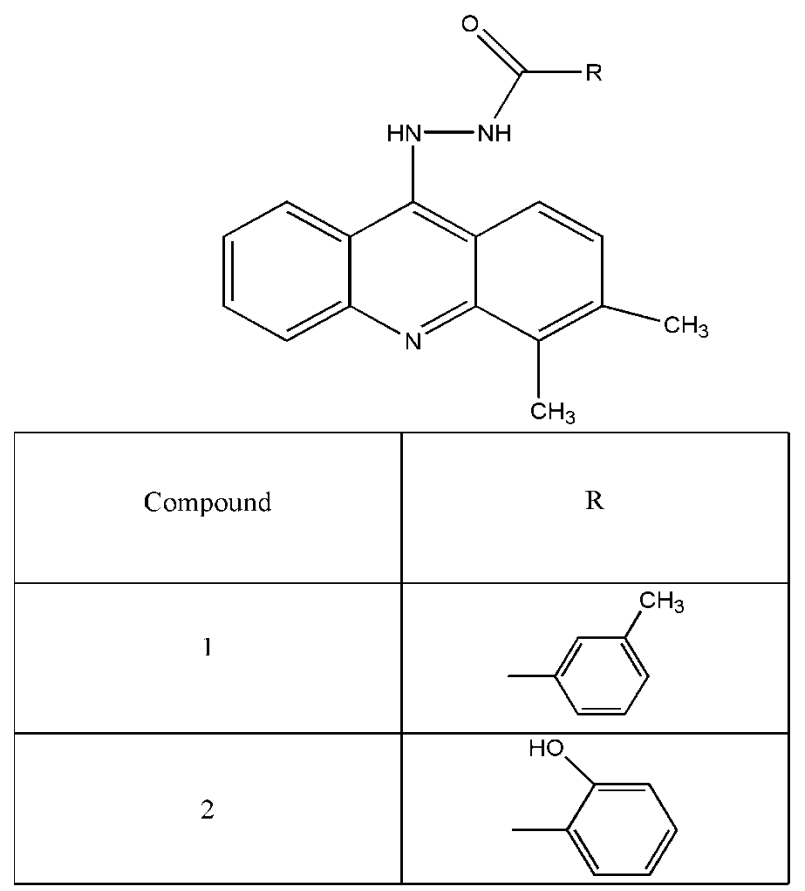

Figure 5. Acridinyl derivatives with selective aspartic protease activity.

\begin{tabular}{|l|l|l|}
\hline & \\
\hline
\end{tabular}

Figure 6. Acridine derivatives proposed to have antimalarial activity or activity against $\beta$-hematin formation. 


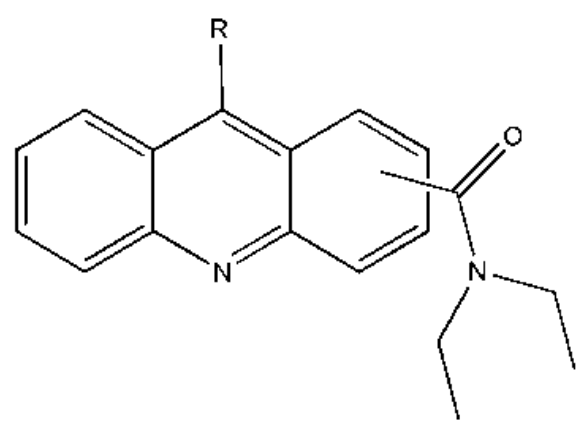

\begin{tabular}{|l|c|c|c|c|}
\hline Compound & 1 & 2 & 3 & 4 \\
\hline Ring sub & 3 & 3 & 2 & 2 \\
\hline R & &
\end{tabular}

Figure 8. Acridine derivatives with anti-herpes activity.<smiles>CN(C)c1ccc(Nc2c3ccc(NC(=O)CCN4CCCC4)cc3nc3cc(NC(=O)CCN4CCCC4)ccc23)cc1</smiles>

Figure 9. Chemical structure of BRACO-19.

\section{ANTIBACTERIAL ACTIVITY OF ACRIDINE DERIVATIVES}

STEWART (1973) synthesized derivatives of acridine with carbamic and thiocarbamic acid esters, urea and thiourea substituents at C9 (Fig. 10). Compounds containing thiourea group (I and II) showed antibacterial activity against Staphylococcus aureus, Proteus vulgaris, Salmonella pullorum, Salmonella typhimurium, Escherichia coli, Klebsiella pneumoniae and Diplococcus pneumoniae. Compound II inhibited also Proteus mirabilis, Streptococcus pyogenes and Pasteurella multocida. 


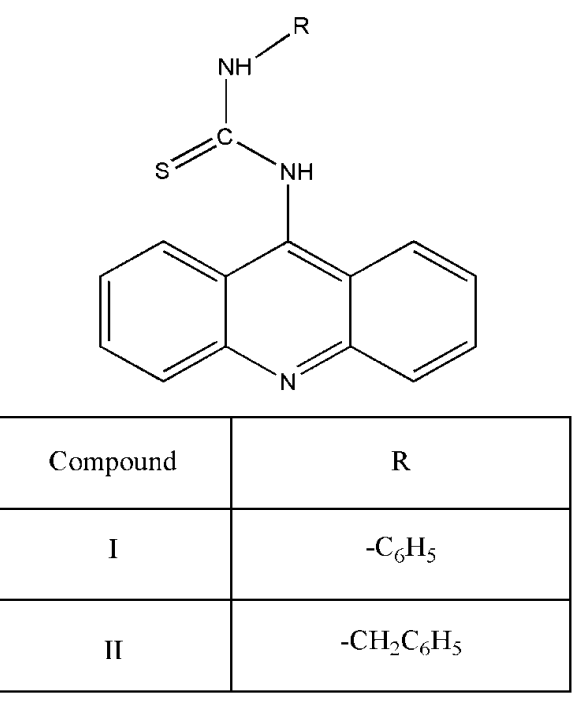

Figure 10. Chemical structures of acridine derivatives with thiourea substituents at C9 evaluated for antibacterial activity.

ALBERT (1966) conducted research on antibacterial activity of acridines and found parameters obligatory for this activity. These parameters include cation formation, high levels of ionization at neutral $\mathrm{pH}$ and planar molecule surface area. Electronic conjugation between nitrogen atom in acridine ring and amino group and resulting ionization were responsible for their high activity. Positions C3, C6 and C9 were also important for antibacterial activity (ALBERT et al., 1945). DNA intercalation of some aminoacridines was responsible for antibacterial activity and this led to anticancer compounds development (LERMAN, 1963).

SINGH et al. (2011) synthesized benzotriazole substituted acridines with aim to determine their antibacterial activity. Compounds 1a and 1b (Fig. 11) showed moderate antibacterial activity, probably due to unsubstituted aromatic amino group, whereas compounds $2 \mathrm{a}$ and $2 \mathrm{~b}$ showed good antibacterial activity. These authors suggested that presence of $-\mathrm{OCH}_{3}$ or $-\mathrm{CH}_{3}$ at $\mathrm{C} 2$ position of acridine ring increased antibacterial activity.<smiles>[R]c1ccc2nc3ccccc3c(Nc3ccccc3N)c2c1</smiles><smiles>[R]c1ccc2nc3ccccc3c(N3N=NC4C=CC=CC43)c2c1</smiles>

\begin{tabular}{|c|c|}
\hline Compound & $R$ \\
\hline $1 \mathrm{a}$ & $-\mathrm{OCH}_{3}$ \\
\hline $1 \mathrm{~b}$ & $-\mathrm{-H}_{3}$ \\
\hline $2 \mathrm{a}$ & $-\mathrm{-CH}_{3}$ \\
\hline $2 \mathrm{~b}$ & $-\mathrm{CH}_{3}$ \\
\hline
\end{tabular}

Figure 11. Compounds with moderate (1a-b) and good (2a-b) antibacterial activity. 
According to KUDRYAVTSEVA et al. (2017), 9-oxoacridines have antibacterial properties which are result of DNA intercalation. They synthesized derivatives of 9oxoacridines and acridine-9-carboxylic acid which had 5-nitrofurantoin as a substituent. Antimicrobial activity of compounds 1 and 3 (Fig. 12) was comparable to standard (ethacridine lactate), compound 1 had more potent inhibition effect compared to standard, while 4 and 5 showed moderate activity. Compound without 5-nitrofurantoin as a substituent (3) had the lowest activity against tested strains.<smiles>[R8]c1cc([R6])c2c(c1)c(=O)c1ccccc1n2[13CH2]</smiles>

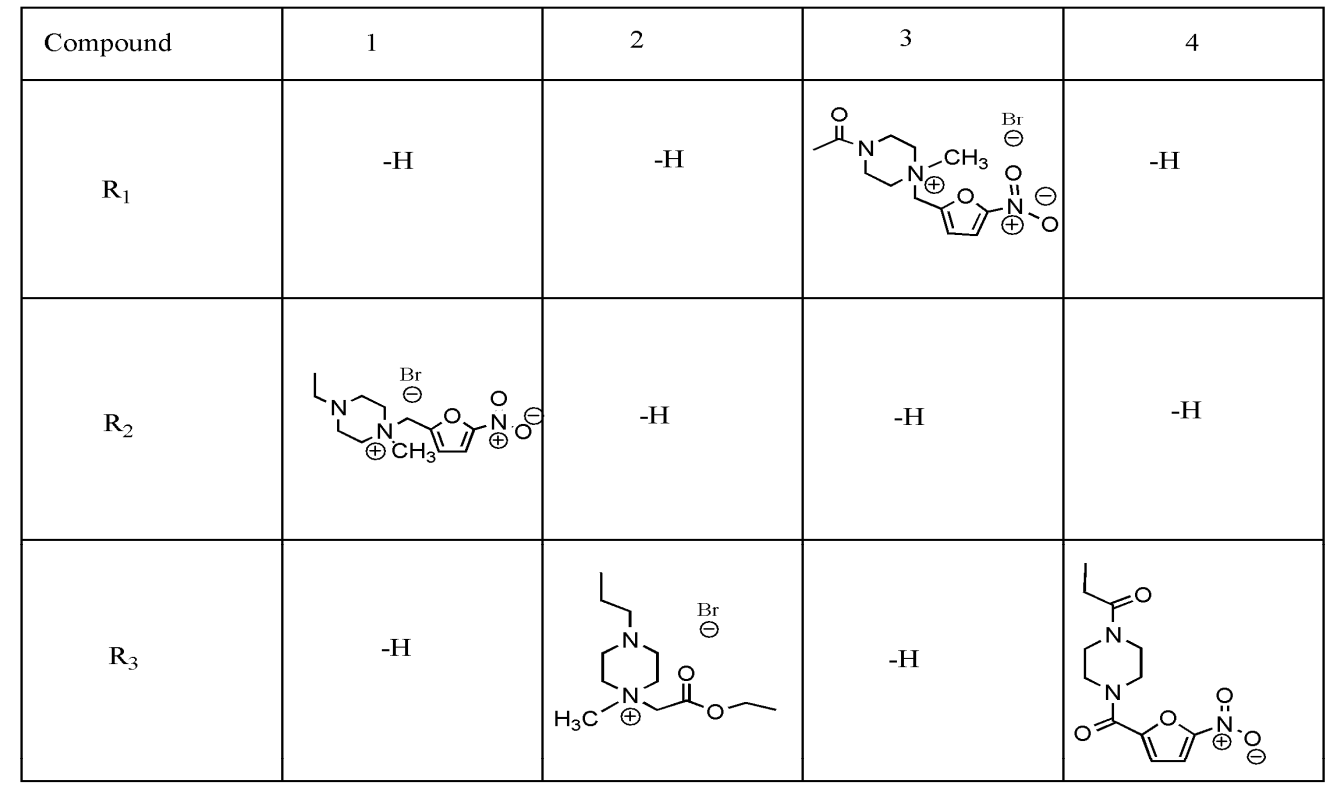

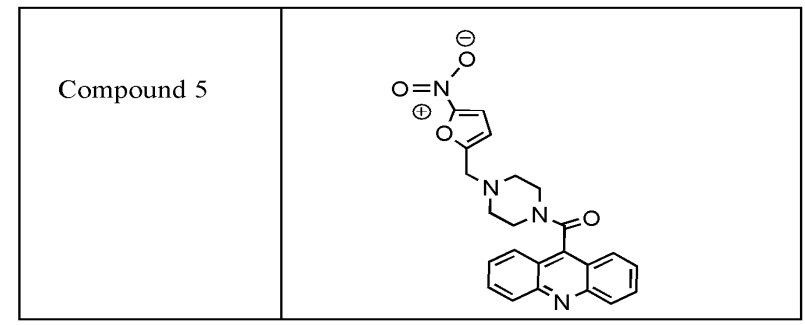

Figure 12. Derivatives of 9-oxoacridines and acridine-9-carboxylic acid.

\section{ANTITUMOR ACTIVITY OF ACRIDINE DERIVATIVES}

GAO et al. (1998) conducted quantitative structure-activity relationship analysis (QSAR) of 9-anilinoacridines with antitumor activity (including inhibitory activity on tumor cells and binding to DNA). They suggested that electronic effects of substituents affected drug's binding site. Hydrophobicity affected the entrance of the drug to the active site and 
substituent's steric effects influenced binding to the active site. On the basis of the previous work (GAO et al., 1998), Bacherikov et al. (2005) synthesized a series of 5-(9acridinylamino)anisidines, such as 5-(9-acridinylamino)- $m$-anisidines (AMAs), 5-(9acridinylamino)-o-anisidines (AOAs) and 5-(9-acridinylamino)- $p$-anisidines (APAs) (Fig. 13), in order to investigate inhibition of tumor cell growth in different cell cultures, topoisomerase II inhibition and interaction with DNA.

\begin{tabular}{|c|c|c|c|}
\hline 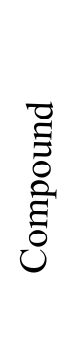 & (c) & (l) & (n) \\
\hline \multirow{2}{*}{$\mathrm{a}$} & $\mathrm{R}_{1}=\mathrm{H}$ & $\mathrm{R}_{1}=\mathrm{H}$ & $\mathrm{R}_{1}=\mathrm{H}$ \\
\hline & $\mathrm{R}_{2}=\mathrm{H}$ & $\mathrm{R}_{2}=\mathrm{H}$ & $\mathrm{R}_{2}=\mathrm{H}$ \\
\hline \multirow[b]{2}{*}{$\mathrm{b}$} & $\mathrm{R}_{1}=\mathrm{CH}_{3}$ & $\mathrm{R}_{1}=\mathrm{CH}_{3}$ & $\mathrm{R}_{1}=\mathrm{CH}_{3}$ \\
\hline & $\mathrm{R}_{2}=\mathrm{H}$ & $\mathrm{R}_{2}=\mathrm{H}$ & $\mathrm{R}_{2}=\mathrm{H}$ \\
\hline \multirow{2}{*}{$\mathrm{c}$} & $\mathrm{R}_{1}=\mathrm{CONHCH}_{2} \mathrm{CH}_{2} \mathrm{~N}\left(\mathrm{CH}_{3}\right)_{2}$ & $\mathrm{R}_{1}=\mathrm{CONHCH}_{2} \mathrm{CH}_{2} \mathrm{~N}\left(\mathrm{CH}_{3}\right)_{2}$ & $\mathrm{R}_{1}=\mathrm{CONHCH}_{2} \mathrm{CH}_{2} \mathrm{~N}\left(\mathrm{CH}_{3}\right)_{2}$ \\
\hline & $\mathrm{R}_{2}=\mathrm{H}$ & $\mathrm{R}_{2}=\mathrm{H}$ & $\mathrm{R}_{2}=\mathrm{H}$ \\
\hline \multirow{2}{*}{$\mathrm{d}$} & $\mathrm{R}_{1}=\mathrm{CONHCH}_{3}$ & $\mathrm{R}_{1}=\mathrm{CONHCH}_{3}$ & $\mathrm{R}_{1}=\mathrm{CONHCH}_{3}$ \\
\hline & $\mathrm{R}_{2}=\mathrm{CH}_{3}$ & $\mathrm{R}_{2}=\mathrm{CH}_{3}$ & $\mathrm{R}_{2}=\mathrm{CH}_{3}$ \\
\hline \multirow{2}{*}{ e } & $\mathrm{R}_{1}=\mathrm{CONHCH}_{2} \mathrm{CH}_{2} \mathrm{~N}\left(\mathrm{CH}_{3}\right)_{2}$ & $\mathrm{R}_{1}=\mathrm{CONHCH}_{2} \mathrm{CH}_{2} \mathrm{~N}\left(\mathrm{CH}_{3}\right)_{2}$ & $\mathrm{R}_{1}=\mathrm{CONHCH}_{2} \mathrm{CH}_{2} \mathrm{~N}\left(\mathrm{CH}_{3}\right)_{2}$ \\
\hline & $\mathrm{R}_{2}=\mathrm{CH}_{3}$ & $\mathrm{R}_{2}=\mathrm{CH}_{3}$ & $\mathrm{R}_{2}=\mathrm{CH}_{3}$ \\
\hline
\end{tabular}

Figure 13. Structures of 5-(9-acridinylamino)- $m$-anisidines (AMAs) 1a-e; 5-(9-acridinylamino)$o$-anisidines (AOAs) 2a-e; 5-(9-acridinylamino)-p-anisidines (APAs) 3a-e.

Previous reports (CAIN et al., 1975) showed that $-\mathrm{OCH}_{3}$ group, with electron-donating effect on the aniline ring of 9-anilinoacridine derivatives, increased antitumor potency and it was suggested that replacing $-\mathrm{CH}_{3}$ group with $-\mathrm{OCH}_{3}$ may increase cytotoxicity of 5-(9acridinylamino)toluidines.

CHANG et al. (2003) showed that 5-(9-acridinyl- amino)toluidine derivatives with $\mathrm{CONHCH}_{2} \mathrm{CH}_{2} \mathrm{~N}\left(\mathrm{CH}_{3}\right)_{2}$ and $-\mathrm{CH}_{3}$ substituents at $\mathrm{C} 4$ and $\mathrm{C} 5$ of the acridine ring were more toxic than the parent AHMA (3-(9-acridinylamino)-5-hydroxymethyl- aniline), in contrast to the simple 5-(9-acridinylamino)toluidines. According to these results, it was easy to define factors that influence the cytotoxicity of 9-anilinoacridines.

BACHERIKOV et al. (2005) showed that AOA (2e) (Fig. 13) was the most potent agent among tested compounds. These authors also suggested that the drug/DNA binding affinity was dominant factor that affects their cytotoxicity.

LYAKHOV et al. (1997) synthesized acridinyl- amino acids and their methyl esters and investigated their cytostatic activity using root test. The polymethylene chain's length influence on the character of the action of synthesized compounds was examined (Fig. 14). 


\begin{tabular}{|c|c|c|c|}
\hline Compound & $\mathrm{R}$ & Compound & $\mathrm{R}$ \\
\hline 4 & $-\mathrm{CH}_{2}^{-}$ & 16 & (D) $-\mathrm{CH}(\mathrm{i}-\mathrm{Bu})-$ \\
\hline 5 & $-\left(\mathrm{CH}_{2}\right)_{2-}^{-}$ & 17 & (L)-CH(sec-Bu)- \\
\hline 6 & $-\left(\mathrm{CH}_{2}\right)_{3}-$ & 18 & (D)-CH(sec-Bu)- \\
\hline 7 & $-\left(\mathrm{CH}_{2}\right)_{4}^{-}$ & 19 & $(\mathrm{~L})-\mathrm{CH}\left(\mathrm{CH}_{2} \mathrm{Ph}\right)-$ \\
\hline 8 & $-\left(\mathrm{CH}_{2}\right)_{5^{-}}$ & 20 & (D)-CH( $\left.\mathrm{CH}_{2} \mathrm{Ph}\right)$ \\
\hline 9 & (L) $-\mathrm{CH}\left(\mathrm{CH}_{3}\right)-$ & 21 & $(\mathrm{~L})-\mathrm{CH}\left(\mathrm{CH}_{2} \mathrm{Ind} \mathrm{d}^{*}\right)$ \\
\hline 10 & (D)-CH(CH$)-$ & 22 & (D)-CH(CH $\left.2 \mathrm{CH}^{*}\right)-$ \\
\hline 11 & (L)-CH(i-Pr)- & 23 & $(\mathrm{~L})-\mathrm{CII}\left(\mathrm{CH}_{2} \mathrm{CII}_{2} \mathrm{SCII}_{3}\right)$ \\
\hline 12 & (D)-CH(i-Pr)- & 24 & (D)- $\mathrm{CH}\left(\mathrm{CH}_{2} \mathrm{CH}_{2} \mathrm{SCH}_{3}\right)-$ \\
\hline 13 & (L) $-\mathrm{CH}(\mathrm{n}-\mathrm{Pr})-$ & 25 & $(\mathrm{~L})-\mathrm{CH}\left(\mathrm{CH}_{2} \mathrm{OH}\right)-$ \\
\hline 14 & (D)-CH(n-Pr)- & 26 & (D) $-\mathrm{CH}\left(\mathrm{CH}_{2} \mathrm{OH}\right)-$ \\
\hline 15 & (L) $-\mathrm{CH}(\mathrm{i}-\mathrm{Bu})-$ & 27 & $(\mathrm{~L})-\mathrm{CH}\left(\mathrm{CH}_{2} \mathrm{Im}^{*} *\right)-$ \\
\hline
\end{tabular}

Ind $^{*}$ - Indolyl-3; Im** - Imidazolyl-4<smiles>[R]Nc1c2ccccc2nc2ccccc12</smiles>

\begin{tabular}{|c|c|c|c|}
\hline Compound & $\mathrm{R}$ & Compound & $\mathrm{R}$ \\
\hline 28 & $(\mathrm{~L})-\mathrm{CH}\left(\mathrm{CH}_{3}\right)-$ & 32 & $-\left(\mathrm{CH}_{2}\right)_{3^{-}}$ \\
\hline 29 & $(\mathrm{D})-\mathrm{CH}\left(\mathrm{CH}_{3}\right)-$ & 33 & $-\left(\mathrm{CH}_{2}\right)_{4^{-}}$ \\
\hline 30 & $-\mathrm{CH}_{2-}$ & 34 & $-\left(\mathrm{CH}_{2}\right)_{5^{-}}$ \\
\hline 31 & $-\left(\mathrm{CH}_{2}\right)_{2^{-}}$ & & \\
\hline
\end{tabular}

Figure 14. Structures of acridinylamino acids and their methyl esters.

Compounds 30 and 31 had stimulatory effect on the cell-division process, but when used in higher concentrations they showed depressing effect. Stimulatory effect of compound 32 was less pronounced, while compounds 33 and 34 had inhibitory effect even in low concentrations (LYAKHOV et al., 1997). They also concluded that there were no significant differences in cytotoxicity of acridinylamino acids and corresponding methyl esters.

SONDHI et al. (2010) synthesized and evaluated a series of acridine derivatives (1a-o and $2 \mathrm{a}-\mathrm{g}$ ) for anti-inflammatory and anticancer activities. The most active compounds with 
anticancer activity were $1 \mathrm{~g}$ and $1 \mathrm{~m}$. Compounds $2 \mathrm{~d}, 2 \mathrm{f}$ and $2 \mathrm{~g}$ also showed good anticancer activity due to electronic and stereochemical effects of substituents (Fig. 15).

\begin{tabular}{|c|c|c|c|c|c|c|}
\hline \multirow[t]{2}{*}{$\bar{\Xi}$} & \multicolumn{3}{|l|}{1} & \multicolumn{3}{|l|}{2} \\
\hline & $R_{1}$ & $\mathrm{R}_{2}$ & $\mathrm{R}_{3}$ & $\mathbf{R}_{1}$ & $\mathrm{R}_{2}$ & $\mathrm{R}_{3}$ \\
\hline a & & -II & $-\mathrm{OCH}_{3}$ & & $-\mathrm{OCH}_{3}$ & $-H$ \\
\hline b & & $-\mathrm{OClI}_{3}$ & $-\mathrm{H}$ & & $-\mathrm{OCH}_{3}$ & $-H$ \\
\hline c & & $-\mathrm{H}$ & $-\mathrm{CH}_{3}$ & & $-\mathrm{OCH}_{3}$ & $-H$ \\
\hline d & & $-H$ & $-\mathrm{OCH}_{3}$ & & $-\mathrm{H}$ & $-\mathrm{CH}_{3}$ \\
\hline e & & $-\mathrm{OCH}_{3}$ & $-H$ & & $-\mathrm{HI}$ & $-\mathrm{CH}_{3}$ \\
\hline$f$ & & $-\mathrm{H}$ & $-\mathrm{CH}_{3}$ & & -II & $-\mathrm{CH}_{3}$ \\
\hline $\mathrm{g}$ & & $-H$ & $-\mathrm{OCH}_{3}$ & & $-\mathrm{H}$ & $-\mathrm{CH}_{3}$ \\
\hline h & & $-\mathrm{OCH}_{3}$ & $-\mathrm{H}$ & & & \\
\hline i & & $-\mathrm{H}$ & $-\mathrm{CH}_{3}$ & & & \\
\hline $\mathrm{j}$ & & $-H$ & $-\mathrm{OCH}_{3}$ & & & \\
\hline k & & $-\mathrm{OCH}_{3}$ & $-\mathrm{H}$ & & & \\
\hline I & & $-\mathrm{H}$ & $-\mathrm{CH}_{3}$ & & & \\
\hline $\mathrm{m}$ & & $-\mathrm{H}$ & $-\mathrm{OCH}_{3}$ & & & \\
\hline$n$ & & $-\mathrm{OCH}_{3}$ & $-\mathrm{H}$ & & & \\
\hline 0 & & $-\mathrm{H}$ & $-\mathrm{CH}_{3}$ & & & \\
\hline
\end{tabular}

Figure 15. Acridine derivatives with anti-inflammatory and anticancer activities.

LANG et al. (2013) synthesized a series of acridine derivatives (Fig. 16). They were focused on the linker between acridine ring and phenyl group and its effect on the antiproliferative activity and DNA-binding ability. Examined cytotoxicity of acridine compounds depends on the structure of the linker between acridine ring and phenyl group. 
The length of the alkyl chain has modest influence on the cytotoxic activity. Compound 1 with the shortest linker showed better cytotoxicity than compounds 2 and 3, so it was suggested that the increase in chain length leads to modest reduction of cytotoxic activity. Introduction of alkoxy or acylamino linker decreased antiproliferative activity. Methyl group at $\mathrm{C} 4$ position and chloro group at $\mathrm{C} 6$ position of acridine ring had no obvious effect on the activity. Finally, compound 7 with $-\mathrm{OCH}_{3}$ group at $\mathrm{C} 2$ position showed greatest cytotoxic activity, affecting DNA topoisomerase I inhibition and caspase-dependent intrinsic mitochondrial pathway.

\begin{tabular}{|c|c|c|c|c|c|c|c|}
\hline Compound & $\mathrm{R}_{1}$ & $\mathrm{R}_{2}$ & $\mathrm{R}_{s}$ & Compound & $\mathrm{R}_{\mathrm{I}}$ & $\mathrm{R}_{2}$ & $\mathrm{R}_{3}$ \\
\hline 4 & $-\mathrm{CH}_{2} \mathrm{O}-$ & $-H$ & $-H$ & 1 & $-\mathrm{CH}_{2} \mathrm{NH}-$ & $-\mathrm{OCH}_{3}$ & $-H$ \\
\hline 5 & $-\mathrm{CONH}-$ & $-\mathrm{H}$ & $-\mathrm{H}$ & 2 & $-\left(\mathrm{CH}_{2}\right)_{2} \mathrm{NH}$ & & $-H$ \\
\hline 6 & $-\mathrm{CH}_{2} \mathrm{NH}-$ & $-I I$ & $-\mathrm{H}$ & 3 & $-\left(\mathrm{CH}_{2}\right)_{3} \mathrm{NH}-$ & $-\mathrm{OCH}_{3}$ & $-\mathrm{H}$ \\
\hline 7 & $-\mathrm{CH}_{2} \mathrm{NEI}-$ & $-\mathrm{OCH}_{3}$ & $-\mathrm{H}$ & 8 & $-\mathrm{CH}_{2} \mathrm{NH}-$ & $-H$ & $-H$ \\
\hline 10 & $-\mathrm{CH}_{2} \mathrm{NH}-$ & $-H$ & $-\mathrm{CH}_{3}$ & 9 & $-\mathrm{CH}_{2} \mathrm{NH}-$ & $-\mathrm{OCH}_{3}$ & $-\mathrm{ClI}_{3}$ \\
\hline
\end{tabular}

Figure 16. Acridine derivatives with different linker between acridine and benzene ring and different substituents on acridine ring.

Effects on DNA synthesis and biochemical pathways, including protein and lipid metabolism, suggest that acridine derivatives may be considered as multi-target compounds.

KUMAR et al. (2013) synthesized a series of 9-aminoacridine derivatives and tested their anticancer activity (Fig. 17). Compounds 1 and 2 exhibited good activity against lung cancer (A-549) and cervical cancer (HeLa) cell lines. SAR analysis showed that substitution by $-\mathrm{OCH}_{3}$ group at position $\mathrm{C} 2$ of acridine ring and $-\mathrm{CF}_{3}$ group at position $\mathrm{C} 3$ of benzene ring attached to the acridine ring resulted in compounds with potent activity against tested cancer cell lines. Also, presence of an electron donating group on acridine ring at position $\mathrm{C} 2$ increased anticancer activity.

DOBRIČIĆ et al. (2016a) designed new acridine derivatives with potential multi-target action [DNA intercalation and inhibition of kinases - Src, MEK and VEGFR-2 (CUI et al., 2016)]. These compounds contain aminoacids (L-glycine, L- and D-phenylalanine, L-histidine and L-asparagine) or corresponding dipeptides in C9 side chain (Fig. 18). Their potential to interact with selected targets was tested using molecular docking studies. Obtained results showed that binding of designed compounds to DNA, with exception of compounds $3,4,5$ and 6, was similar to amsacrine, which was used as standard. Derivatives with lowest binding energies that form key binding interactions with MEK were 4, 6, 9, 10, 11, 12, 13, 15, 16, 18 and 19, with VEGFR-2 were 8, 11 and 16, whereas with Src were 4 and 6. 


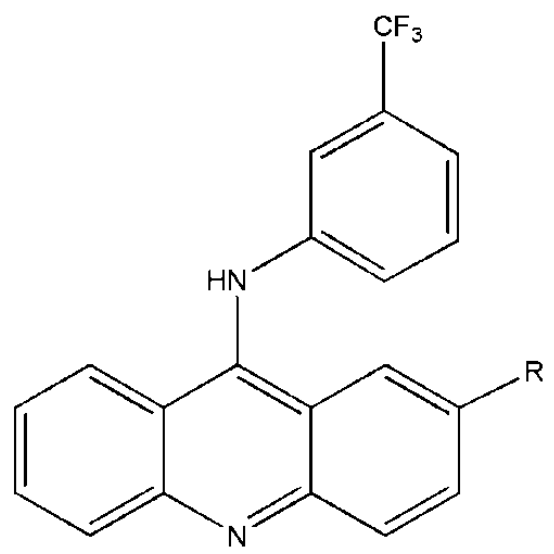

\begin{tabular}{|c|c|}
\hline Compound & $\mathbf{R}$ \\
\hline 1 & $-\mathrm{H}$ \\
\hline 2 & $-\mathrm{OCH}_{3}$ \\
\hline
\end{tabular}

Figure 17. Structure of 9-aminoacridine derivatives tested for anticancer activity.<smiles>[R9]C(=O)c1ccc(Nc2c3ccc([R])cc3nc3c([R9])c([B])c([R9])cc23)cc1</smiles>

Figure 18. Chemical structures of designed acridines with potential multi-target action.

The same authors designed additional group of 9-aminoacridine derivatives (Fig. 19) and examined their interaction with same targets (DNA, Src, MEK and VEGFR-2) using molecular docking (DOBRIČIĆ et al., 2016b).

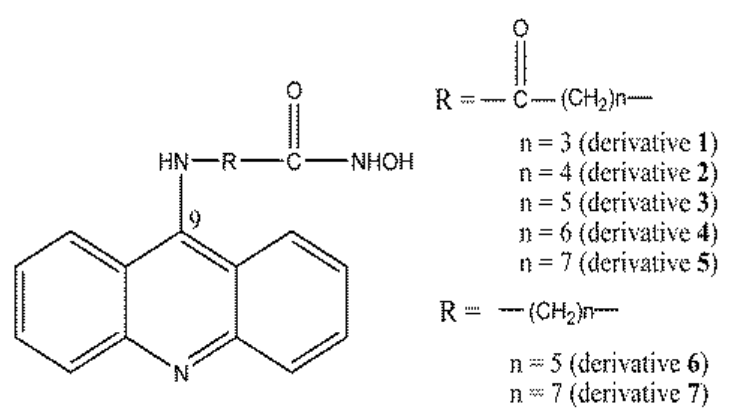

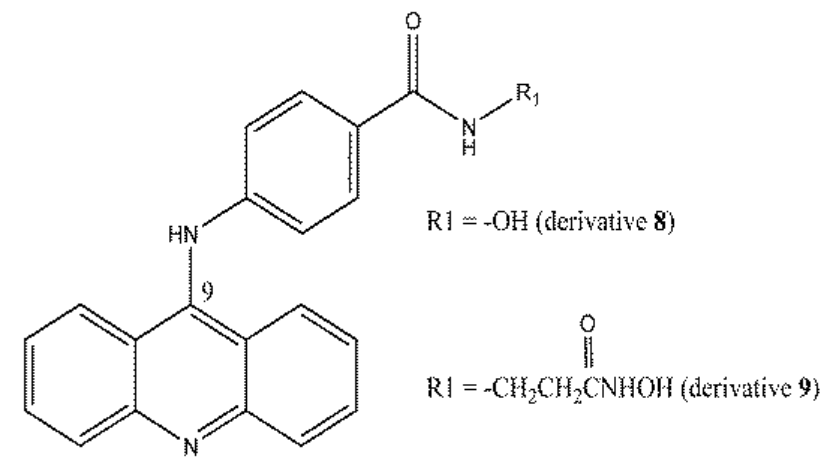

Figure 19. Additional group of 9-aminoacridine derivatives with potential multi-target action. 
All compounds showed DNA binding affinity similar to amsacrine. Compounds 3, 4, 5, 6, 7 and 9 formed significant interactions with MEK, whereas compounds 1, 3, 7 and 8 showed significant binding to Src. Derivatives 3, 4, 5, 8 and 9 formed some of the important interactions with VEGFR-2, but according to their binding energies, moderate activity towards VEGFR-2 can be expected.

\section{CONCLUSION}

Although introduced in $19^{\text {th }}$ century, acridine derivatives are still of scientific interest. In this review, acridine derivatives with various biological activity (antiparasitic, antiviral, antibacterial and antiproliferative), as well as their structure-activity relationship analyses are presented. Although several mechanisms of their action are known, only important are discussed here. It can be concluded that dominant mechanisms are DNA intercalation and interactions with enzymes.

\section{Acknowledgments}

This work was financially supported by the Ministry of Education, Science and Technological Development, Belgrade, Republic of Serbia, as part of Project No.172041.

\section{References:}

[1] Albert, A. (1966): The Acridines: their Preparation, Physical, Chemical, and Biological Properties and Uses ( $2^{\text {nd }}$ ed.). London, Arnold.

[2] Albert, A., Rubbo, S.D., Burvill, M.I. (1949): The influence of chemical constitution on antibacterial activity. Part IV: A survey of heterocyclic bases, with special reference to benzoquinolines, phenanthridines, benzacridines, quinolines and pyridines. The British Journal of Experimental Pathology 30 (3): 159-175.

[3] Albert, A., Rubbo, S.D., Goldacre, R.J., Davey, M.E., Stone, J.D. (1945): The influence of chemical constitution on antibacterial activity. Part II: A general survey of the acridine series. British Journal of Experimental Pathology 26 (3): 160-192.

[4] AleKsić, M.M., KapeTAnović, V. (2013): Electrochemical biosensors as a tool for the investigation of DNA structure, damage and interaction with other molecules. Facta Universitatis, Series: Physics, Chemistry and Technology 11 (1): 27-43. doi: 10.2298/FUPCT1301027A

[5] Aleksić, M.M., Kapetanović, V. (2014): An overview of the optical and electrochemical methods for detection of DNA - Drug Interactions. Acta Chimica Slovenica 61 (3): 555-573.

[6] Artusi, S.A., Nadai, M., Perrone, R., Biasolo, M.A., Palu, G., Flamand, L., CALISTRI, A., Richter, S.N. (2015): The Herpes Simplex Virus-1 genome contains multiple clusters of repeated G-quadruplex: Implications for the antiviral activity of a Gquadruplex ligand. Antiviral Research 118: 123-131. 
doi: 10.1016/j.antiviral.2015.03.016

[7] Azim, M.K., Ahmed, W., Khan, I.A., RaO, N.A., Khan, K.M. (2008): Identification of acridinyl hydrazides as potent aspartic protease inhibitors. Bioorganic \& Medicinal Chemistry Letters 18 (9): 3011-3015. doi: 10.1016/j.bmcl.2008.02.060

[9] Bacherikov, V.A., Chang, J.Y., Lin, Y.W., Chen, C.H., Pan, W.Y., Dong, H., Lee, R.Z., CHOU, T.C., SU, T.L. (2005): Synthesis and antitumor activity of 5-(9acridinylamino)anisidine derivatives. Bioorganic \& Medicinal Chemistry 13 (23): 65136520. doi: 10.1016/j.bmc.2005.07.018

[10] Baguley, B. C., NASH R. (1981): Antitumour activity of substituted 9-anilinoacridines Comparison of In vivo and In vitro testing systems. European Journal of Cancer 17 (6): 671-679. doi: 10.1016/0014-2964(81)90271-1

[11] BRowning, C.H. (1937): Chemotherapeutic antiseptics. Edinburgh Medical Journal 44: 497-521.

[12] Browning, C. H. (1964): Chemotherapy with antibacterial dyestuffs. In: Schhitzer, R.J., Hawking, F. (eds.) Experimental Chemotherapy, New York, Academic Press.

[13] Browning, C.H., Cohen, J.B., Gaunt, R., Gulbransen, R. (1922): Relationship between antiseptic action and chemical constitution with special reference to compounds of the pyridine, quinoline, acridine and phenazine series. Proccedings of the Royal Society 93: 329-366.

[14] Burger, A.M., Dai, F., Schultes, C.M., Reszka, A.P., Moore, M.J., Double, J.A., NEIDLE, S. (2005): The G-quadruplex-interactive molecule BRACO-19 inhibits tumor growth, consistent with telomere targeting and interference with telomerase function. Cancer Research 65 (4): 1489-1496. doi: 10.1158/0008-5472.CAN-04-2910

[15] Cain, B.F., Atwell, G.J., Denny, W.A. (1975): Potential antitumor agents. 16. 4'(Acridin-9-ylamino)methanesulfonanilides. Journal of Medicinal Chemistry 18 (11): 1110-1117. doi: 10.1021/jm00245a013

[16] Chang, J.Y., Lin, C.F., Pan, W.Y., Bacherikov, V., Chou, T.C., Chen, C.H., Dong, H., Cheng, S.Y., Tasi, T.J., Lin, Y.W., Chen, K.T., Chen, L.T., Su, T.L. (2003): New analogues of AHMA as potential antitumor agents: synthesis and biological activity. Bioorganic \& Medicinal Chemistry 11 (23): 4959-4969.

doi: 10.1016/j.bmc.2003.09.001

[17] Chavalitshewinkoon, P., Wilairat, P., Gamage, S., Denny, W., Figgitt, D., RALPH, R. (1993): Structure-Activity Relationships and Modes of Action of 9Anilinoacridines against Chloroquine-Resistant Plasmodium falciparum In Vitro. Antimicrobial agents and chemotherapy 37 (3): 403-406.

[18] Choudhury, M., BAsu, R. (1995): Studies of charge transfer interaction of nucleotides with proflavine. Journal of Photochemistry and Photobiology A: Chemistry 85 (1-2): 89-92. doi: 10.1016/1010-6030(94)03888-2

[19] Coggeshall, L.T. (1952): The treatment of malaria. The American Journal of Tropical Medicine and Hygiene 1 (1): 124-131.

[20] Cui, Z., Li, X., Li, L., Zhangb, B., GaO, C., Chen, Y., Tan, C., LiU, H., Xie, W., Yang, T., JIANG, Y. (2016): Design, synthesis and evaluation of acridine derivatives as multitarget Src and MEK kinase inhibitors for anti-tumor treatment. Bioorganic \& Medicinal Chemistry 24 (2): 261-269. doi: 10.1016/j.bmc.2015.12.011 
[21] Diculescu, V.C., Chiorcea-Paquim, A.-M., Oliveira-Brett, A.M. (2016): Application of a DNA-electrochemical biosensor. Trends in Analytical Chemistry, 79: 23-36. doi: 10.1016/j.trac.2016.01.019

[22] Dobričić, V., Pantić, J., Aleksić, M., Brborić, J., Vladimirov, S., Čudina, O. (2016a): Design of acridine derivatives with potential antiproliferative activity based on multi-target action. Book of the Abstracts, MuTaLig COST ACTION CA15135, Lugano $(\mathrm{CH})$.

[23] Dobričić, V., Pantić, J., Aleksić, M., Brborić, J., Vladimirov, S., Čudina, O. (2016b): Molecular docking studies of novel 9-aminoacridine derivatives with potential multi-target-based antiproliferative activity. Book of the Abstracts, MuTaLig COST ACTION CA15135, Budapest (HU).

[24] Ferguson, L.R., DenNy, W.A. (2007): Genotoxicity of non-covalent interactions: DNA intercalators. Mutation Research 623 (1-2): 14-23. doi: 10.1016/j.mrfmmm.2007.03.014

[25] Figgitt, D., Denny, W., Chavalitshewinkoon, P., Wilairat, P., Ralph, R. (1992): In Vitro Study of Anticancer Acridines as Potential Antitrypanosomal and Antimalarial Agents. Antimicrobial Agents and Chemotherapy 36 (8): 1644-1647. doi: 10.1128/AAC.36.8.1644

[26] GaO, H., Denny, W.A., Garg, R., Hansch, C. (1998): Quantitative structure-activity relationships (QSAR) for 9-anilino- acridines: a comparative analysis. ChemicoBiological Interaction, 116 (3): 157-180. doi: 10.1016/S0009-2797(98)00085-4

[27] GeORghiou, S. (1975): On the nature of interaction between proflavine and DNA. Photochemistry and Photobiology 22 (3-4): 103-109. doi: 10.1111/j.17511097.1975.tb08820.x

[28] Girousi, S.T., Alexiadou, D.K., IoAnnou, A.K. (2008): An electroanalytical study of the drug proflavine. Microchimica Acta 160 (4): 435-439. doi: 10.1007/s00604-0070812-1

[29] Goodell, J.R., MadhoK, A.A., Hiasa, H., Ferguson, D.M. (2006): Synthesis and evaluation of acridine- and acridone-based anti-herpes agents with topoisomerase activity. Bioorganic \& Medicinal Chemistry 14 (16): 5467-5480.

doi: 10.1016/j.bmc.2006.04.044

[30] Graebe, C., Lagodzinski, K. (1893): Ueber Acridon. Justus Liebigs Annalen der Chemie 276 (1): 35-53. doi: 10.1002/jlac.18932760104

[31] Harrison, R.J., Cuesta, J., Chessari, G., Read, M.A., Basra, S.K., ReszKa, A.P., Morrell, J., Gowan, S.M., Incles, C.M., Tanious, F.A., Wilson, W.D., Kelland, L.R., NEIDLE, S. (2003): Trisubstituted acridine derivatives as potent and selective telomerase inhibitors. Journal of Medicinal Chemistry 46 (21): 4463-4476. doi: $10.1021 / \mathrm{jm} 0308693$

[32] Jiang, D., Tam, A., Alagappan, M., Hay, M.P., Gupta, A., Kozak, M., SolowCordero, D.E., Lum, P.Y., DenKo, N., Giaccia, A.J., Le, Q.-T., Niwa, M., KoOnG, A.C. (2016): Acridine Derivatives as Inhibitors of the IRE1 $\alpha-X B P 1$ Pathway Cytotoxic to Human Multiple Myeloma. Molecular Cancer Therapeutics 15 (9): 2055-2065. doi: 10.1158/1535-7163.MCT-15-1023

[33] Kudryavtseva, T.N., Lamanov, A.Y., Klimova, L.G., Nazarov, G.V. (2017): Synthesis and antimicrobial activity of acridine carboxylic acid derivatives containing a piperazine moiety. Russian Chemical Bulletin, International Edition 66 (1): 123-128. doi: 10.1007/s11172-017-1709-8 
[34] Kumar, S., Guha, M., Choubey, V., Maity, P., Bandyopadhyay, U. (2007): Antimalarial drugs inhibiting hemozoin (beta-hematin) formation: a mechanistic update. Life Sciences 80 (9): 813-828. doi: 10.1016/j.lfs.2006.11.008

[35] Kumar, R., Kaur, M., Kumari, M. (2012): Acridine: A versatile heterocyclic nucleus. Acta Pharmaceutica - Drug research 69 (1): 3-9.

[36] Kumar, P., Kumar, R., Prasad, D.N. (2013): Synthesis and anticancer study of 9aminoacridine derivatives. Arabian Journal of Chemistry 6: 79-85.

doi: 10.1016/j.arabjc.2012.04.039

[37] Lang, X., Li, L., Chen, Y., Sun, Q., Wu, Q., Liu, F., Tan, C., Liu, H., GaO, C., Jiang, Y. (2013): Novel synthetic acridine derivatives as potent DNA-binding and apoptosisinducing antitumor agents. Bioorganic \& Medicinal Chemistry 21: 4170-4177. doi: 10.1016/j.bmc.2013.05.008

[38] LeRman, L.S. (1963): The structure of the DNA-acridine complex. Proceedings of the National Academy of Sciences, USA 49 (1): 94-102.

[39] LiJeskić, N., AleKsić, M.M., KAPETANOviĆ, V. (2014): In situ evaluation of interaction between varenicline and DNA using DNA-electrochemical biosensor. Proceedings of $12^{\text {th }}$ International Conference on Fundamental and Applied Aspects of Physical Chemistry, Belgrade, Serbia: 430-433.

[40] Lyakhov, S.A., Suveyzdis, Y.I., Bykhovskaya, O.V., Isko, N.M., Andronati, S. A., LiTVINOVA, L.A. (1997): Biological active acridine derivatives. 3. Acridinylaminoacids and their esters: synthesis and cytostatic activity. Pharmazie 52 (7): 560-561. doi: 10.1002/chin.199746202

[41] NASIM, A., BRYCHCY, T. (1979): Genetic effects of acridine compounds. Mutation Research 65 (4): 261-288. doi: 10.1016/0165-1110(79)90005-8

[42] Opsenica, I., Burnett, J. C., Gussio, R., Opsenica, D., Todorović, N., Charlotte, A.L., Sciotti, R.J., Gettayacamin, M., Basilico, N., Taramelli, D., Nuss. J.E., Wanner, L., Panchal, R.G., Šolaja, B.A., Bavari, S. (2011): A chemotype that inhibits three unrelated pathogenic targets: the botulinum neurotoxin serotype A light chain, P. falciparum malaria, and the Ebola filovirus. Journal of Medicinal Chemistry 54 (5): 1157-1169. doi: 10.1021/jm100938u

[43] Pantić, J., Aleksić, M. M., Dobričić, V., Čudina, O., Brborić, J., Vladimirov, S. (2016): Electrochemical oxidation and interaction of 9-chloroacridine with DNA at glassy carbon electrode. Proceedings of $13 t^{h}$ International Conference on Fundamental and Applied Aspects of Physical Chemistry, Belgrade, Serbia 2: 383-386.

[44] Peacocke, A.R., Skerrett, J.N.H. (1956): The interaction of aminoacridines with nucleic acids. Transactions of the Faraday Society 52: 261-279.

[45] Pepin, G., Nejad, C., Thomas, B.J., Ferrand, J., McArthur, K., Bardin, P.G., WiLliams, B.R.G., GANTIER, M. P. (2017): Activation of cGAS-dependent antiviral responses by DNA intercalating agents. Nucleic Acids Research 45 (1): 198-205. doi: 10.1093/nar/gkw878

[46] Pontinha, A.D.R., Sparapani, S., Neidle, S., Oliveira-Brett, A.M. (2013): Triazoleacridine conjugates: redox mechanisms and in situ electrochemical evaluation of interaction with double-stranded DNA. Bioelectrochemistry 89: 50-56.

doi: 10.1016/j.bioelechem.2012.08.005 
[47] Popoff, I.C., Engle, A.R., Whitaker, R.L., Singhal, G.H. (1971): Antimalarial agents. 8. Ring-substituted bis(4-amino- phenyl)sulfones and their precursors. Journal of Medicinal Chemistry 14 (12): 1166-1169. doi: 10.1021/jm00294a006

[48] Radulović, V., AleKsić, M., Kapetanović, V. (2012a): An electrochemical study of the adsorptive behaviour of varenicline and its interaction with DNA. Journal of the Serbian Chemical Society 77 (10): 1409-1422. doi: 10.2298/JSC120420073R

[49] Radulović, V., Aleksić, M., Kapetanović, V. (2012b): Voltammetric determination of Varenicline and its interaction with DNA. 14th International Conference on Electroanalysis, Portorož, Slovenia, Abstracts 178: 1-40.

[50] Ramstein, J., Dourlent, M., LenG, M. (1972): Interaction between proflavine and deoxyribonucleic acid influence of DNA base composition. Biochemical and Biophysical Research Communications 47 (4): 874-882.

doi: 10.1016/0006-291X(72)90574-8

[51] Read, M., Harrison, R.J., Romagnoli, B., Tanious, F.A., Gowan, S.H., Reszka, A.P.,Wilson, W.D., Kelland, L.R., NeIDle, S. (2001): Structure-based design of selective and potent G quadruplex-mediated telomerase inhibitors. Proceedings of the National Academy of Sciences of the United States of America 98 (9): 4844-4849. doi: 10.1073/pnas.081560598

[52] Reinhardt, C., Travis, A.S. (2000): Heinrich Caro and the Creation of Modern Chemical Industry. Netherlands, Springer.

[53] Rowe, T.C., Chen, G.L., Hsiang, Y.-H., LIU, LF (1986): DNA damage by antitumor acridines mediated by mammalian DNA topoisomerase II. Cancer Research 46 (4): 2021-2026.

[54] Santelli-Rouvier, C., Pradines, B., Berthelot, M., Parzy, D., Barbe, J. (2004): Arylsulfonyl acridinyl derivatives acting on Plasmodium falciparum. European Journal of Medicinal Chemistry 39 (9): 735-744. doi: 10.1016/j.ejmech.2004.05.007

[55] Singh, N.P., Kumar, R., Prasad, D.N., Sharma, S., SILAKARI, O. (2011): Synthesis and antibacterial activity of benzotriazole substituted acridines. International Journal of Biological Chemistry 5 (3): 193-199. doi: 10.3923/ijbc.2011.193.199

[56] Sondhi, S.M., Singh, J., Rani, R., Gupta, P.P., Agrawal, S.K., SaXena, A.K. (2010): Synthesis, anti-inflammatory and anticancer activity evaluation of some novel acridine derivatives. European Journal of Medicinal Chemistry 45 (2): 555-563. doi: 10.1016/j.ejmech.2009.10.042

[57] Stewart, J.T. (1973): Synthesis and biological activity of 9-substituted acridines, Journal of Pharmaceutical Sciences 62 (8): 1357-1358. doi: 10.1002/jps.2600620830

[58] Suveyzdis, Y.A., Lyakhov, S.A., Litvinova, L.A., Rybalko, S.I., Dyadyun, S.T. (2000): Antiviral activity of acridinylaminoalcohols and acridinylaminoacid esters. Pharmaceutical Chemistry Journal 34 (10): 528-529. doi: 10.1023/A:1010303112897

[59] Yu, X. -M., Ramiandrasoa, F., Guatzoyan, L., Pradines, B., Quintino, E., Gadelle, D., Forterre, P., Cresteil, T., Mahy, J.-P., Pethe, S. (2012): Synthesis and biological evaluation of acridine derivatives as antimalarial agents. ChemMedChem 7 (4): 587-605. doi: 10.1002/cmdc. 201100554

[60] Živanović, M., Aleksić, M., Ostatna, V., Doneux, T., Paleček, E. (2010): Polylysine-catalyzed hydrogen evolution at mercury electrodes. Electroanalysis 22 (1718): 2064-2070. 